Acta vet. scand. $1961,2,254-266$.

From the Department of Physiology, Endocrinology and Bloodgrouping, The Royal Veterinary and Agricultural College, Copenhagen, Denmark.

\title{
IMMUNOELECTROPHORETIC INVESTIGATIONS ON THE BLOOD SERUM OF ADULT PIGS
}

By

E. Brummerstedt-Hansen

During investigations to find better methods for fractionating separate protein components Grabar \& Williams (1953), developed a technique which permitted far greater fractionation of the components than any hitherto used. They called the method "immunoelectrophoretic analysis" because it consisted of a combination of electrophoresis and immunological reaction. This results in a very detailed fractionation. Heremans (1960) records 25 components at least where, by paper-electrophoresis, only 6 different fractions had been obtained. Very recently this result has been somewhat improved by using other buffers (Aronsson \& Grönwall (1957), and by substituting other transport media for the paper (Smithies 1955). The value of immunoelectrophoresis may be increased further by using specific staining methods, characterization reactions (Grabar \& Burtin 1960), autoradiography (Scheidegger \& Buzzi 1959) and by changing technical details the method then affords considerable improvement in protein identification; in human medicine it has become very useful in diagnosing diseases which cause changes in the clinical picture of the blood serum, f. inst. chronic infections and various tumorous growth (Grabar \& Burtin 1960; Clausen 1960; Heremans 1960 and others). The method can also be used in purity determinations of protein preparations (Grabar \& Burtin 1960; Scheidegger 1957) and in genetic investigations (Hirschfeld 1960) as well as in investigations of other biological fluids, urine, cerebrospinal fluid, milk etc. However, there are also short- 
comings connected with immunoelectrophoresis. Grabar (1960) mentions $f$. inst. that standardization of the necessary antibodies is difficult, that the method requires that the substance for investigation be an antigen, or at least hapten and that the method by nature, is largely qualitative.

\section{PRINCIPLE}

An immunoelectrophoretic analysis begins by an electrophoretic separation in an agar gel formed on an oblong glass plate of which each of the two ends rests on its own electrode vessel. The connection between the agar gel and the buffer in the electrode vessels is made by bridges of filter paper. Electrophoresis usually lasts two hours at a low potential gradient. During this process the proteins will be distributed in spots, the center of which falls on a line drawn from pole to pole through the point at which the serum sample was added.

When the sample is sufficiently subdivided, the electric current is turned off; then, at a convenient distance from the migration line, and parallel with it, a groove is made in the agar and filled with antibody antagonistic to the serum sample in question. A double diffusion now takes place, for the components of both the protein and the antibody will diffuse into the agar gel. When antigen and antibody encounter each other in equivalent quantities a precipitin reaction will occur. This will appear as whitish arcs in the transparent agar, one arc for each protein fraction. In this way it is possible to subdivide proteins with the same migration ability, because they do not necessarily show the same diffusion rate in the agar, nor the same antigen effect. If two different proteins should not be found to be recognizable as different by an immunoelectrophoretic test, they should have the same electrophoretic mobility, the same diffusion rate and the same antigenic effect and the probability for this seems to be extremely slight (Grabar 1960). When precipitation ceases the plates can be read against a dark background with oblique light. Better, but requiring more time, is to dry the plate after first washing it in saline and then rinsing it in destilled water. The agar gel when dried forms a form coating on the glass plate and may then be stained with the protein stain commonly used. The specimen may also be subjected to specific characterization reactions. Readings may then be made with a magnifying glass or a photographic projector. 
Electrophoresis in agar gel was first used by Gordon and collaborators (1949). The medium has many advantages due to its high moisture content. Further, it is a diffusion medium well adapted for antigens and antibodies which are to be investigated for precipitation (Oudin 1952 and 1955; Ouchterlony 1949).

\section{TECHNIQUE}

Grabar's method is used on glass plates $13 \times 18 \mathrm{~cm}$. This is expensive as rather large amounts of antibodies are required. In 1955 Scheidegger devised a micro-method in which ordinary microscopic slides were used. This was much cheaper and became widely known. It was used in a slightly modified form (Mansa Olsen 1960) in the present investigations.

\section{Antibody.}

Rabbits were used for producing antibodies. They were first immunized with sow serum (I and II immunization periods) and then with mixed serum from slaughter pigs (III immunization period). Using antibodies from I immunization period it was only possible to demonstrate few components in the pig serum. This condition was bettered with the following immunization so that with the mixed anti-serum (rabbit 143, 145, 146 and 147) it was possible after III immunization period to demonstrate $20-25$ different compounds in the pig serum. In I immunization the rabbits are inoculated with serum several times with a one day interval, in immunizations II and III, only four injections were given two by two inter-muscularly at intervals of about 3 months. One week after the last injection the rabbits were tapped of $40 \mathrm{ml}$. blood from an ear vein. From this, blood serum was prepared and placed in small test tubes, each contained sufficient serum for a one days requirement of antibodies. In this way repeated freezing and thawing could be avoided.

A g a $\mathrm{M}$ edium.

Special Agar-Noble Difco, a particularly pure agar was used in the investigation. A solution was prepared containing $8 \mathrm{~g}$. agar, 200 cc. destilled water and 200 cc. of the buffer solution described below. The solution when ready for use contained nearly $2 \%$ agar. The mixture was heated over a boiling water bath. Then 1 vol. percent of a 1 percent solution of mertiolate was 
added as an antiseptic. The liquid agar solution was then poured into test tubes where it stiffened and placed in a refrigerator for later use. Thus prepared and stored, agar gel can keep for a long time.

Buffers olution.

In the electrode vessels a veronal buffer of the Michaelis type was used $(\mu=0.1 \mathrm{pH} \mathrm{8.6})$.

Its composition was: $0.05-\mathrm{m}$ sodium diethyl barbiturate

0.005-m diethyl barbituric acid

$0.05-\mathrm{m}$ sodium acetate.

Preparation of agar plates.

The required quantity of agar gel is melted over a boiling water bath. With a warm pipette 2 cc. agar solution is distributed on each slide where it spreads evenly and soon becomes rigid. The slide is placed in a holder over which is laid a form with the desired apertures for antigens and antibodies. These apertures may vary in appearance depending on the requirements of the analysis. Fig. 1A shows an agar plate furnished with apertures for comparing the reaction of two antigens to the same antibody. Fig $1 \mathrm{~B}$ shows a comparison of the reaction of two antibodies to the same antigen.

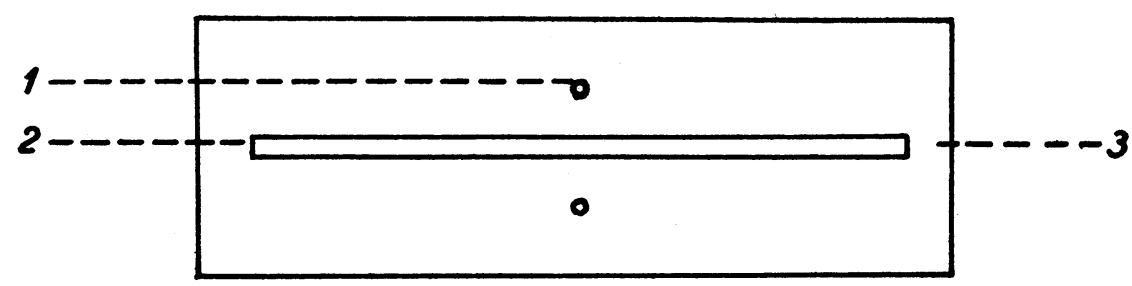

A

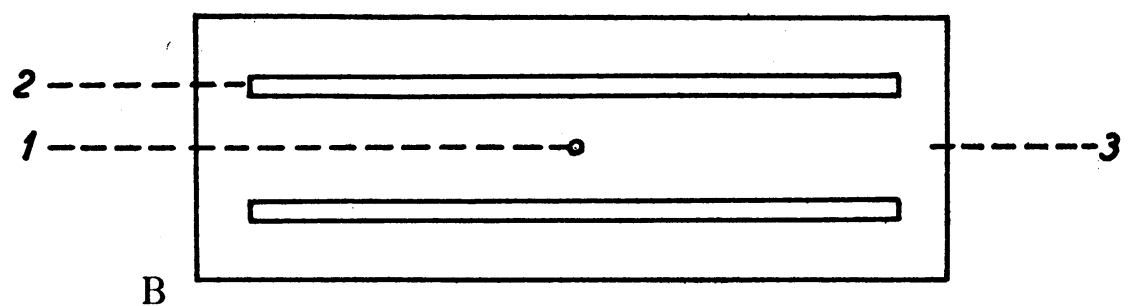

Fig. 1 A \& B. Illustrations of cuts: 1 antigen, 2 antibody, 3 agargel. 
The antigen reservoir is established as follows: By means of a blunt injection neddle passed through an aperture in the form, a cylinder is sucked out of the gel. Using a drawing pen the contours of the antibody reservoir are traced on the form; the agar strip is not removed before electrophoresis has terminated to avoid disturbing the current passing through the gel. With a Carlsberg pipette the required amount of antigen is placed in the reservoir. The preparation is now ready for the first part of the analysis.

Electrophoresis.

The electrophoretic separation was made in a special apparatus of suitable size, designed for preparations the size of ordinary slides. The principle is the same as that used in other

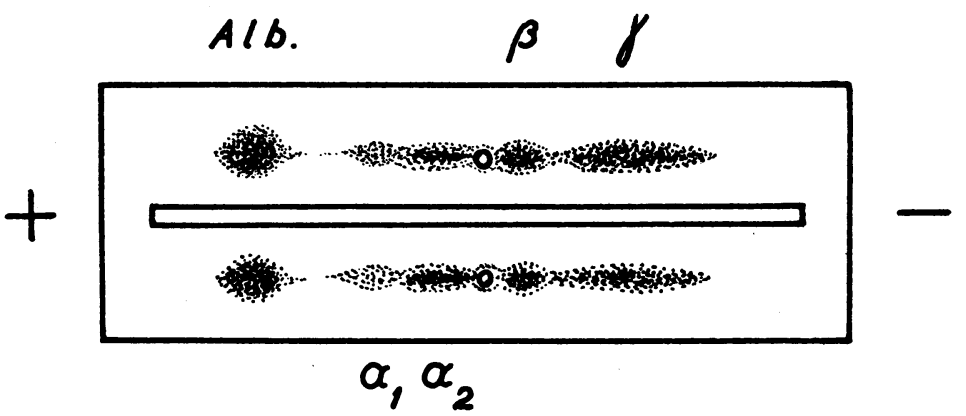

F i g. 2. The partition of the proteins after the electrophoresis. The preparation is fixed, dried and finally stained with amidoblack $10 \mathrm{~B}$.

apparatus for electrophoresis. Seven agar slides are placed in the apparatus. The connection between agar slides and buffer is made with fine filter paper. The slides are subjected to electrophoresis: $25 \mathrm{~V}$ for 5 min., then $20 \mathrm{~V}$ for 2 hours. During this time the proteins will be distributed in the gel so that albumen is nearest the anode and $\gamma$-globulin nearest the cathode. The other globulins are distributed between these two extremers. Protein distribution is a result of the effect of two forces on the proteins, i.e. the electric current and the electroendosmosis which cause a general displacement of liquid in the gel (Grabar 1959 and Grabar $\&$ Burtin 1960). This appears as a dilution on the anode side. If the investigation is stopped at this point by fixation of the preparation, drying and staining, we obtain a picture as seen in Fig. 2.

At the termination of electrophoresis the agar strip is re- 
moved the contours of which have already been drawn in. In the resulting furrow are placed the necessary amounts of antibodies and the preparation is placed in a moist chamber for $\mathbf{2 4}$ hours. At the end of this period diffusion (Fig. 3) is complete.

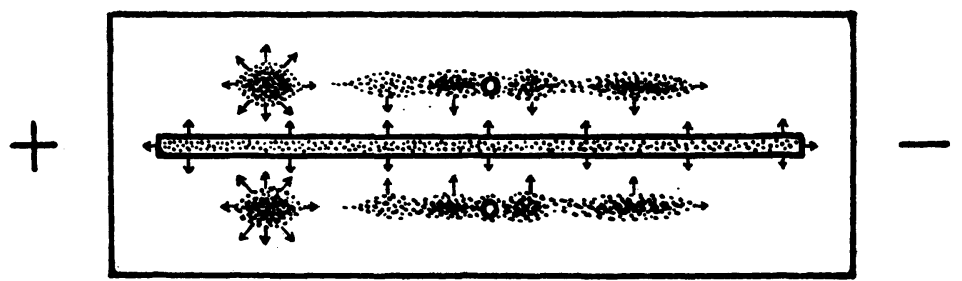

F i g. 3. Rough sketch of the double diffusion.

Already after a couple of hours the first precipitin arcs are visible (seen in the albumen and $\beta_{1}$-region, Fig. 4). At the end of twenty-four hours the complete picture appears as shown in Fig. 5.

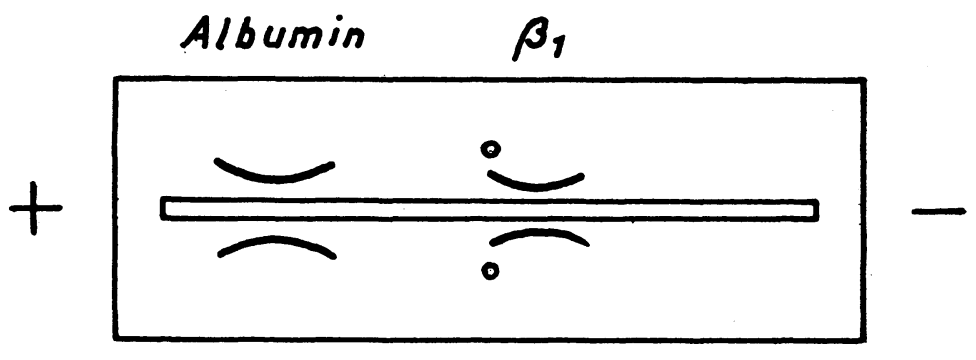

F i g. 4. The first arcs appearing during the diffusion period.

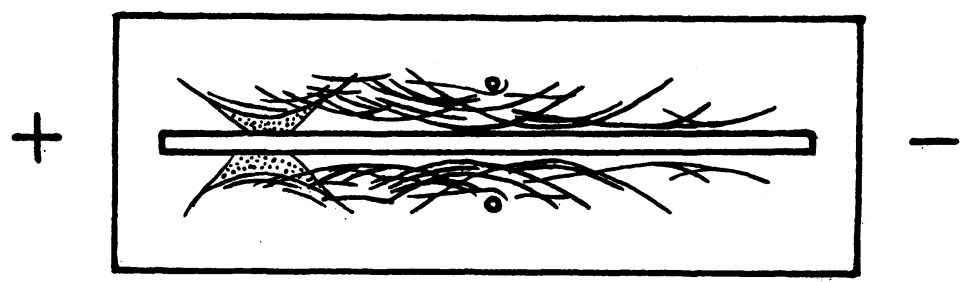

F i g. 5. The complete preparation (nat. size).

Antigens and antibodies which were not precipitated are now washed out for two days in saline $(0.92 \%)$ the solution being changed frequently. After this the sodium chloride was leached for twenty-four hours with destilled water and the slides 
set aside to dry. The gel is now a rigid transparent film on the slide.

\section{S t a in ing.}

The preparations are stained with amido black $10 \mathrm{~B}$ in some cases, and in others with azocarmine.

In amido black staining the preparations are left $7-8$ minutes in a solution of amido black in a mixture of metanol, glacial acetic acid and water. Thereafter they are rinsed in four successive baths of the above described solution, five minutes in each bath, and left to dry.

In azocarmine staining (Uriel in Grabar \& Burtin: Analyse immuno-électrophorétique 1960) the preparations are stained for one hour in a solution of azocarmine in acetic acid-acetate buffer and then bleached in two successive baths of two percent acetic acid, and one hour in each bath with subsequent drying (addition of glycerol as described by Uriel was omitted).

The preparations are read with a magnifying apparatus. The reading gives magnification slightly more than 5.5 times, projected on paper, where with a pencil it is possible to trace the shape of the precipitin arcs.

Material and quantity proportion. To clarify how the immunoelectrophoretic picture of a normal pig appears, 75 blood samples of pigs were taken in a pig slaughterhouse. A sample was drawn from every fifth pig series as far as possible, to obtain samples of unrelated pigs. Serum was drawn from the blood samples. Of this $3-4 \mu \mathrm{l}$. was used in each analysis. Together with $50 \mu \mathrm{l}$. antibodies, this amount of antigen will produce a great number of arcs. If only $1-2 \mu$ l. antigen are used, there will be fewer and less distinct arcs, whereas a moderate increase in amount of antigen used does not change the result to any great extent.

Under the described relation between antigens and antibodies, the quantity of antigen is so great that in weak concentrations, proteins are also able to produce arcs, cf. Williams \& Grabar (1955). The picture will therefore consist of a series of sharp lines always present, plus some shorter lines, the presence and placement of which are less constant.

\section{RESULTS}

In human medicine there have been many difficulties in finding a satisfactory designation of all the many arcs which 
appear in immunoelectrophoresis. However, there is now a serviceable terminology which is used in the present paper. In this the arcs are grouped according to their electrophoretic mobility thus: $\alpha_{1}, \alpha_{2}, \beta_{1}$ etc. and the separate arcs in the groups are numbered according to migration distance determined by the location of the topmost point of the arc in the migration direction. Thus an arc in the $\alpha_{1}$-field is e.g. designated $\alpha_{1}-2$ and the next arc towards the cathode $\alpha_{1}-3$. Gradually as the separate arcs are identified, the designations may be more clearly characterized, f. inst. $\alpha_{1}$-lipoprotein, $\alpha_{2}$-macroglobulin, and in the case of some few arcs, even more simply (coeruloplasmin, haptoglobin, etc.).

Albumen and prealbumen are the fractions which migrate the greatest distance towards the anode. In immunoelectrophoresis, albumen appears as the largest arc of all those located entirely within the anode field. In human serum samples an arc is described which corresponds to a prealbumen, but it has not yet been possible to positively determine this form by immunoelectrophoresis in pig serum. However, there is scarcely any doubt that it will be found, as prealbumen for instance, may be demonstrated by an ordinary electrophoresis (Uriel \& Grabar 1956) and author's own investigations. That no prealbumen arc appears with the antibodies found up to date must be due to a slight antigen effect of prealbumen and therefore the homologous antibody of that substance is lacking in the antibody until now in use.

$\alpha_{1}$-globulin. The $\alpha_{1}$-field together with $\alpha_{2}$-field comprises the most complicated part of the preparation due to the large content of components in different serum concentrations. The reading is consequently difficult, but several arcs are constant and may be used as fixed points of departure in the interpretation.

In the curvature of the albumen arc there are three arcs, here designated $\alpha_{1}-1, \alpha_{1}-2$ and $\alpha_{1}-3$. The first mentioned arc may be split at ends, all three arcs are not necessarily present simultaneously. The weakest and most often missing is $\operatorname{arc} \alpha_{1}-3$. $\alpha_{1}-4$, when seen in its full extent, is a very long arc; it begins in the concavity of the albumen arc and extends into the $\alpha_{2}$-field. However, after it has passed the albumen arc, it quite often becomes indistinct. $\alpha_{1}-5$ is a quite well defined arc. Sometimes it varies slightly in its placement in respect to $\alpha_{2}-1$, as it may cut across that arc, or even lie quite within the concavity of $\alpha_{2}-1$. $\alpha_{1}-6$ and $\alpha_{1}-7$ are laterally placed in respect to $\alpha_{1}-5 . \alpha_{1}-7$ lies on the cathode part of the albumen arc. In many preparations it 
is possible to see a smaller, but sharply defined arc in contact with $\alpha_{1}-7$.

$\alpha_{2}$-globulin. $\alpha_{2}-1$ is a very long arc and it stretches all the way from the albumen field to the cathode side of the well. $\alpha_{2}-2$ lies far out laterally. Staining the dried agar slides with oil red as described by Uriel (in Grabar \& Burtin: Analyse immunoélectrophorétique, 1960), demonstrates that the arc contains lipoprotein and it may therefore be designated $\alpha_{2}$-lipoprotein. If, at the termination of electrophoresis, the agar plate is stained with the same stain, three colored fields are discernible, viz. the prealbumen, $\alpha_{1}$-and $\alpha_{2}$. By immunoelectrophoresis however, only the one stained $\alpha_{2}$-arc is obtained. I was to be expected that no stained prealbumen arc would be formed. All above, and the failure of a stained $\alpha_{1}$-arc to appear is presumably due to the same combination of causes as in the case of prealbumen. In the concavity of $\alpha_{2}-1$ arc lies an $\alpha_{2}-3$ arc and often an $\alpha_{2}-4$ arc. $\alpha_{2}-5$ is a short strong arc which stretches towards the filling hole. It is crossed by an arc of the same appearance $\alpha_{2}-6$. These two arcs may cover each other on the cathode or anode part. Most likely it is a question of two almost identic proteins. $\alpha_{2}-7$ is a distinct arc which often turns round the filling hole. There is a slurred transition to $\alpha_{2}$-lipoprotein. On the lateral side of $\alpha_{2}-7$ and parallel with it a smaller arc is often found. $\alpha_{2}-8$ lies on the border of the $\beta_{1}$-field, between $\beta_{1}-1$ and $\beta_{1}-2$ but slightly nearer the anode field than these two.

$\beta_{1}$-field. Through the entire cathode section of the preparation, the readings are much easier. There are fewer arcs and their performance is more certain. $\beta_{1}-1$ is a large arc placed with one half on either side of the filling hole. The same is true of $\beta_{1}-2 . \beta_{1}-3$ is, beside the albumen and $\gamma$-arc the strongest and best defined arc and has the same placement and appearance in all preparations. In the concavity of $\beta_{1}-3$ lies a fine little arc, $\beta_{1}-4$.

$\beta_{2}$-field. In this field are only two arcs, $\beta_{2}-1$ and $\beta_{2}-2$. In many pigs, however, very far on the cathode field, is an arc which may be designated $\beta_{3}-1$.

$\gamma$-globulin. $\gamma$-globulin forms the longest arc of all. It stretches from the filling hole far into the cathode field. For quite a distance through the $\beta_{1}$-field the arc is almost a straight line, it then turns laterally. Shortly before the end the $\gamma$-arc may divide and form two arcs. 

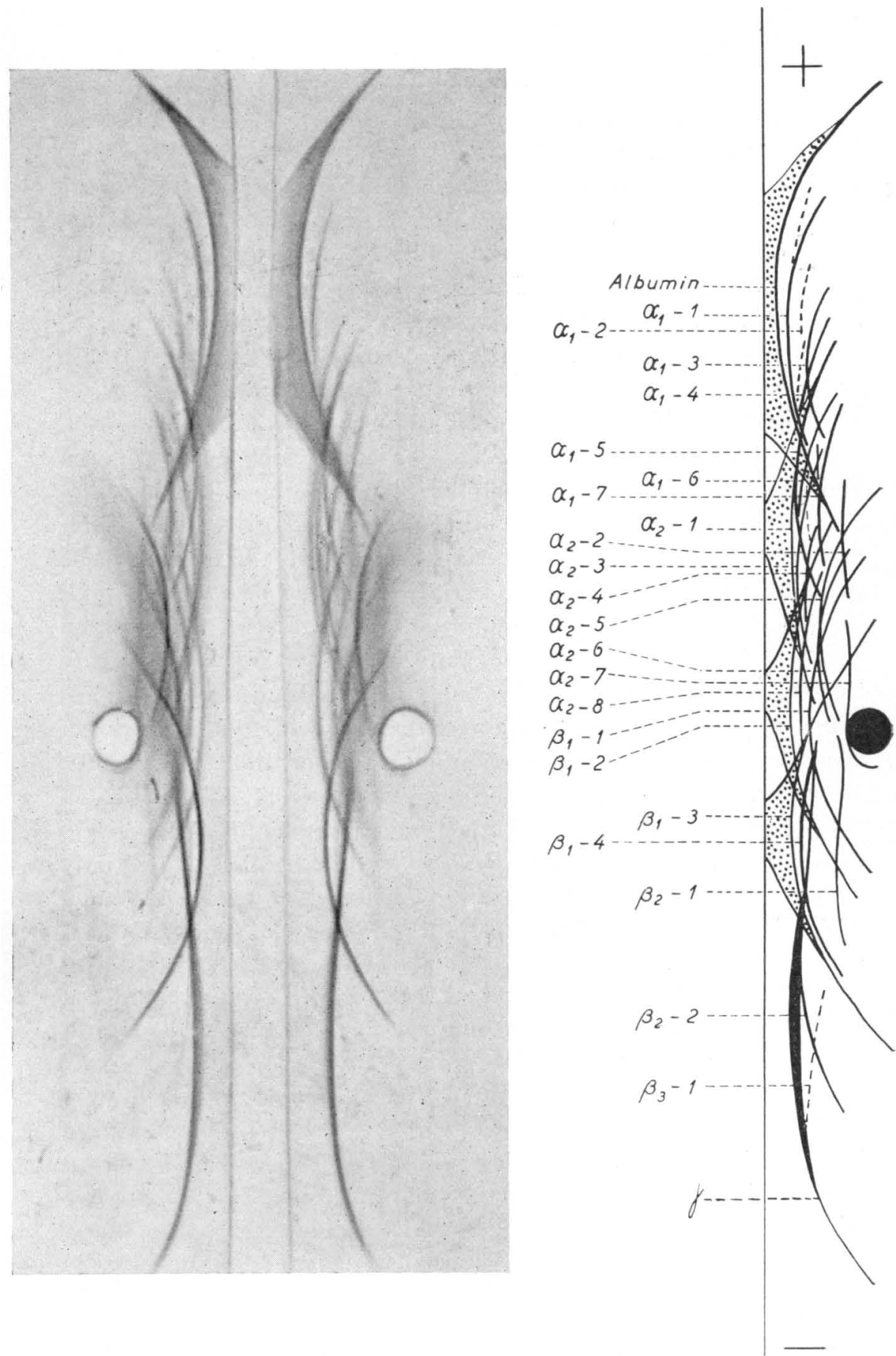

F i g. 6. Photo of the complete preparation stained with amidoblack (left) and the same prep. in which the shape of the precipitin arcs is traced with Indian ink after projection on paper by means of the magnifying apparatus (right). Magn. approx. $3 \times$ (Phot. L. E. Lindegaard). 


\section{DISCUSSION}

As may be understood from the above, immunoelectrophoresis is a very sensitive apparatus with which to deal and extremely dependent on the presence of a good antibody. Experiments are now being made to produce antibodies in other animals than rabbits in the hope of a further elucidation of the protein components in pig serum and by immunizing rabbits with another antigen to perhaps obtain an antibody with new components.

The picture presented in these investigations should therefore not be taken as the complete picture. Furthermore all the arcs (Fig. 6) do not always appear simultaneously. Albumen, $\alpha_{1}-1, \alpha_{2}$ $-1, \alpha_{2}-2, \alpha_{2}-5, \alpha_{2}-8, \beta_{1}-2, \beta_{1}-3$ and $\gamma$ may be considered rigid arcs. They are arcs which vary but little from one preparation to another. Many of the other arcs are likewise always present but subjected to variation in placement and clarity. It is probable that possible genetic variations should be sought as well in these arcs as in arcs of more sporadic nature. To certify the placement of the arcs and elucidate what they represent, future investigations must utilize the methods mentioned at the beginning of this paper and use purified proteins both in direct analyses of the arc of the protein and in absorption experiments. However, to produce pure protein fractions is a complicated procedure for even $0.1 \%$ impurity is considered sufficient to create a precipitation arc (Grabar \& Burtin 1960). The only commercial pig protein preparation on the market is pig albumen which is stated to be $\mathbf{9 7} \%$ pure. This shows a very large albumen arc far into the anode field, but also two quite strong ares in $\alpha_{2}{ }^{-}$and $\beta_{1}$-fields. Veterinary investigators are therefore hindered in their work by an insufficiency of pure culture protein preparations ready for immediate use.

In addition to use in genetic investigations it is to be expected that the method will be found useful also in veterinary medicine in investigations of physiological variations and pathological changes in serum and other biological fluids. Further studies will presumably elucidate these conditions.

\section{ACKNOWLEDGMENTS}

The present investigations were made at the Department for Physiology, Endocrinology and Bloodgrouping. To the chief of the department, Professor Dr. med. vet. Johs. Moustgaard I am indebted for providing excellent working conditions and for great 
interest in the work. Furthermore I wish to thank cand. pharm. B. Mansa Otsen (Statens Seruminstitut, Copenhagen) for very valuable help and suggestions.

\section{REFERENCES}

Aronsson, T. \& Grönwall, A.: Scand. J. Clin. Lab. Invest. 1957, 9, 338. Clausen, J.: Oversigt over immunelektroforesens teoretiske grundlag og praktiske anvendelse med særligt henblik på serumproteiner. 1960.

Gordon, A. H., Keil, B. \& Sebesta, K.: Nature 1949, 164, 498.

Grabar, P. \& Williams, C. A.: Biochim. biophys. Acta 1953, 10, 193.

Grabar, P.: Methods of biochem. anal. 1959, Vol. VII 1-38.

Grabar, P. \& Burtin, P.: Analyse immuno-électrophorétique 1960.

Heremans, J.: Les globulines sériques du système gamma 1960 .

Hirschfeld, J.: Science Tools vol. $7 \mathrm{nr} .2,18-251960$.

Mansa Olsen, B.: Personal communication.

Ouchterlony, Ö.: Ark. Kemi, Min. Geol. vol B 26, 14, 1-9 1949.

Oudin, J.: Methods in med res. Vol. 5, 335, 1952.

Oudin, J.: Ann. Inst. Pasteur 1955, 89, 531.

Scheidegger, J.-J.: Int. Arch. Allergy 1955, 7, 103.

Scheidegger, J.-J. \& Buzzi, C.: Rev. franç. d'études clin. biol. 1957, 2, 895.

Scheidegger, J.-J.: Bull. Soc. chim. biol. 39 suppl. 1, 45, 1957.

Smithies, O.: Biochem. J. 1955, 61, 629.

Uriel, J. \& Grabar, P.: Bull. Soc. chim. biol. 1956, 38, 1253.

Williams, C. A. \& Grabar, P.: J. immunol. 1955, 74, 158.

\section{SUMMARY}

After a description of the principle and technique of immunoelectrophoresis, a survey is given of the results obtained by investigations of adult pigs of the Danish Landrace. The conditions are described which at present must be considered normal and the possibility is mentioned of obtaining further clarity on the elements of serum by production of new antibodies, by specific characterization reactions and pure cultures of the separate protein components. Finally, the possible utilization of the method in veterinary medicine is mentioned.

\section{ZUSAMMENFASSUNG \\ Immunoelektrophoretische Untersuchungen des Blutserums erwach- sener Schweine.}

Nach einer Beschreibung des Prinzips und der Tecknik der Immunoelektrophorese wird eine Uebersicht über die Resultate gegeben, die bisher bei Untersuchungen von Serum erwachsener Schweine der dänischen Landrasse erzielt wurden. Das Bild wird beschrieben, das man zur Zeit als normal betrachten kann; ferner wird die Mäglichkeit diskutiert, weitere Klarheit über die Serumbestandteile bei der Pro- 
duktion neuer Antikärper, die spezifischen Reaktionen und die Reindarstellung der einzelnen Proteinkomponenten zu gewinnen. Schliesslich wird auf die mögliche Anwendung der genannten Methode in der Veterinärmedizin hingewiesen.

\section{RESUME}

Immunelektroforetiske undersøgelser af serum fra voksne svin.

Efter en beskrivelse af immunelektroforesens princip og teknik gives en oversigt over hvilke resultater, der hidtil er opnået ved unders $\varnothing$ gelser af serum fra voksne svin af dansk landrace. Der beskrives det billede, der indtil nu må betragtes som det normale, og diskuteres til slut muligheden for at få yderligere klarhed over serumbestanddelene ved produktion af nye antistoffer, specifikke karakteriseringsreaktioner og renfremstilling af de enkelte proteinkomponenter. Sluttelig anføres metodens mulige anvendelse i veterinærmedicinen.

(Received April 14. 1961). 